\title{
Regarding the Research and
}

Translations of Buddhist Scripture by Nineteenth Century European Religious Studies Scholars: Using Max Müller as an Example*

HONG XIUPING

Nanjing University

bongx@nju.edu.cn

Keywords: European religious studies scholars, Max Müller, translation and research of Buddhist scriptures

DOI: https://dx.doi.org/10.15239/hijbs.01.01.04

Abstract: Max Müller is a representative nineteenth century European scholar of the 'Science of Religion' who strove to break free from the fetters of traditional Christian theology in Europe, by studying Eastern languages, translating Eastern religious scriptures, and using comparative religious studies as a method. He hoped to perform an 'impartial', objective study upon the varied and complicated phenomenon that is religion. His efforts not only promoted the establishment of religious studies as an academic discipline, but

* The essay is the phased achievement of the National Social Science Fund's (National Office for Philosophy and Social Sciences) key project titled 'Study on the Transformation to the Secular World of Modern and Contemporary Buddhism' 近現代佛教入世轉型研究 project (no. 16AZJ003). Professor Sun Yiping 孫亦平 provided a great deal of help over the course of writing this essay, and she is hereby acknowledged for her help. 
also revealed Buddhism's place in the world, opened a door for the Buddhist religion - which had been 'otherised' in the context of the west - to enter Europe, promoted the dissemination of Buddhism in Europe, and deepened Europeans' understanding of Buddhism. At the same time, Müller used comparative linguistics as a model to construct comparative religious studies. He wrote and compiled a series of writings related to Eastern religions, and he regarded translating Buddhist scriptures as a way of recreating the religion's early culture. This promoted the research of Buddhism in Europe and exchanges among Eastern and Western academics. Over the course of translating Sanskrit Buddhist scriptures into English, Müller emphasised performing textual analysis to determine the etymology of concept presented by nouns within these scriptures. He also emphasised performing cross-sectional comparisons involving Buddhism and other religions in order to reveal the cognition of the unique qualities of Buddhist culture. This formed an academic trajectory within European Buddhist studies that placed equal weight on philology and philosophy. Looking back over the translations of Buddhist scriptures and research regarding the religion carried out by nineteenth century European religious studies scholars, it is clear that this has had a significant impact on understandings and dialogues between different religions. It also paved the way for significant exchanges across Eastern and Western academic culture.

$\mathbf{R}$ eligious studies is an academic discipline that performs scientific Rummarisations and comprehensive research upon various forms of religious phenomena exhibited by humanity. It gradually began to flourish in nineteenth century European society. The reasons for this varies, but among them are a particular zeal for Eastern religions exhibited by nineteenth century religious studies academics, a push to break free from the fetters of traditional Christian theology in Europe, by studying Eastern languages, translating Eastern religious scriptures, using comparative religious studies as a method, and the discipline's ability to more impartially and objectively perform research on the numerous and complicated instances of religious phenomena. The most influential figure was F. Max Müller (1823-1900), the English 
University of Oxford Professor of Linguistics. He spread Buddhism throughout Europe via his translations of Buddhist scriptures, which deepened the European understanding of Buddhism and also established rich cultural resources for the religion. At the same time, he also promoted European Buddhist studies and encouraged interactions between Eastern and Western Buddhist culture.

\section{Providing Rich Cultural Resources to Found Religious Studies Through an Understanding of Buddhism}

Max Müller studied Sanskrit in his youth and later went to Oxford University, where he worked on the translation of the Rigveda. From that point on, he developed an interest in India's religions and its ethnic cultures, which prompted him to shift the focus of his research from west to east and from linguistics to mythology and religious studies. Müller believed that religions are naturally connected to language and ethnicity and held the opinion that by learning about an early religion's linguistic state, we can understand that linguistic classifications may also be applied to religious sciences. Furthermore, if there are indeed genealogical relationships between the languages of different ethnic groups, then the world's religions can be studied by linking them via these relationships. Müller thus used comparative philology as a model to construct comparative religious studies, which also demonstrated Buddhism's status as a world religion. Beginning in 1853, Müller wrote a series of books on Eastern religions that included the work Buddhism, which was published in 1862.

On the basis of the detailed research on numerous religions, with a genuine enthusiasm and sincere desire to understand other religions, from a perspective of purely theoretical interest, Max Müller used the various Indian religions as the examples from which to explore the origins and growth of religion as a whole. In his words, 'It is a very old saying that 'we never know a thing unless we know its beginnings'. We may know a great deal about religion, we may have read many of the sacred books, the creeds, the catechisms, and the liturgies of the world, and yet religion itself may be something entirely beyond our grasp unless we are able to trace it back to the deepest 
sources from whence it springs.' ${ }^{\prime}$ Thus, Müller contended that, 'The historical evidence from the world's every religion should be collected, and it needed to be selected and classified in order to find the necessary predecessor of each religion, discover the patterns that restricted their development and those that led to the extinction of human religions, and also to understand the objectives of religions.' ${ }^{2}$ From February to March of 1870, Müller gave four lectures on religious studies at the British Academy of Sciences in London in which he raised a series of questions: In what sense could genuine religious science research be performed? What materials can we use to truly and reliably understand the world's major religions? And by what criteria can we differentiate these religions? Müller's consciousness of such questions provided a path for him to use comparative research methods to study religions.

Max Müller believed that finding the answers to these questions required one to look back to the deepest and most essential connotation of belief among religions; namely, the human desire for the 'infinite'. He stated, 'Religion, in the subjective sense, is a mental faculty, which, independently, nay, in spite of, sense and reason, enables man to apprehend the infinite under different names and under varying disguises. Without that faculty, no religion, not even the lowest worship of idols and fetishes, would be possible. ${ }^{3}$ Although Müller's understanding the nature of religion from the perspective of the 'infinite' received some criticism, it was based on the idea that 'The history of [the] development [of the infinite] is neither more nor less than the history of religion'. This perspective both encompassed and transcended specific religions in order to construct a theoretical

$1 \quad$ Müller, Origin and Growth of Religion, 220 (154): This translation quotes from the original source text, but it should be noted that the author quoted this work in translation in their original text, from the translation by Jin Ze. For this text and later examples, the footnote will give the page number of the quote material in the source material, and in a parenthetical citation the page number of the Chinese version will be provided.

2 Sun, 'Zongjiao de Qiyuan yu Fazhan', 63-64.

3 Müller, Origin and Growth of Religion, 23 (14). 
system for religious studies that was at once comprehensive and integral. ${ }^{4}$ From the perspective of the establishment of religious studies, Müller began with the relationships between language, nationality, and religion, and then divided world religions into three categories, Aryan, Semitic, and Turanian religions, according to belief. This categorisation was done using information from various religious scripts of those religions. Additionally, by combing through the eight religions of these three major groups that had existent scriptures, he was able to reveal the history of Buddhism's evolution, the type of belief it exhibited, and the scope of its dissemination.

Within his works on religion, Max Müller quoted a large number of Buddhist classics, and he compared Buddhism to Christianity, Judaism, Brahmanism, and ancient Persian religions in order to identify similarities, differences, and associations between them. According to Müller, 'Comparison is classification, which is based on the historical forms of various religions throughout the world, and from this we can discover the order and patterns of religions. ${ }^{5}$ He believed that was the true meaning and practical usage of comparative research methods. It was through a comparative study of the beliefs of people across various major religions that Müller was the first to come up with the concept of the 'Science of Religion', ${ }^{6}$ and this also allowed him to establish the discipline of the same name that carries out a 'truly scientific study of the religions of the world'.7 In 1873, Müller compiled the contents of this lecture into a book titled Introduction

\footnotetext{
4 Müller, Origin and Growth of Religion, 55 (38).

5 Lü, 'Preface', 4.

6 Wach, Comparative Study, 1; In this book, Joachim thinks that this concept was used to describe a new discipline that was freed from the 'Philosophy of Religion' and especially from 'Theology'.

7 Müller, Science of Religion, 4 (4): This translation quotes from the original source text, but it should be noted that the author quoted this work in translation in their original text from the translation by Kenneth K. S. Ch'en and Li Peizhu (Ch'en and Li, Zongjiao xue daolun). For this text and later examples, the footnote will give the page number of the quote material in the source material, and in a parenthetical citation the page number of the Chinese version will be provided.
} 
to the Science of Religion. After its publication, this work was recognised by the international academic community as the cornerstone of western religious studies.

In terms of Buddhism, Max Müller's basic view was that Indians of the Aryan family produced both Brahmanism and Buddhism; moreover, he contended that Buddhism originated from Brahmanism, although its religious beliefs and doctrines differed from those of Brahmanism. After a period of development on the land from which it originated, the status of Buddhism began to decline, but it was later brought to the various nations of the Turanian family in the Asian continent, where it took root and assumed an important status. Though Buddhism was originally an Aryan religion, it became the main religion in Turanian society. The expansive dissemination of Buddhism and the far-reaching influence of its scriptures transformed it into a world religion. Müller entered the field of Buddhist studies and began translating Buddhist scriptures to meet the needs of comparative religious studies.

\section{Compiling the Sacred Books of the East; Bolstering Buddhist Research in Europe and Buddhist Cultural Exchanges Between East and West}

We can see from the dissemination of Buddhism in Europe that the majority of early Buddhist scriptures were written in Sanskrit, which is a language classified as part of the Indo-Aryan language family. Starting with his translation of Rigveda, Max Müller spent his life enthusiastically studying Indian religions, including Buddhism. Although he promoted Buddhist translations and Buddhist research at a time when it was simply attributed to Oriental studies or Indian studies, he did manage to open the door for Buddhism-this term that had been 'otherised' in western languages - to enter Europe.

Based on his studies of folklore from Southern Buddhism and Northern Buddhism, Max Müller believed that there were originally 80,000 or 84,000 Buddhist scriptures, but the majority of them had already been lost, and only about 6,000 were left. According to the Lankēvatāra Sütra, the entirety of all Buddhist scriptures and their 
annotations amounts to 39,368,000 letters. The English version of the Bible, on the other hand, purportedly only contains 3,567,000 consonant letters without counting the vowels. Currently, Buddhist scriptures are divided into two categories: Southern Buddhist scriptures are written in Pali, while Northern Buddhist scriptures use Sanskrit. According to estimations, Pali Buddhist scriptures are about twice the length of the Bible, and if they were translated into English, they would likely be four times as long. Tibetan translations of Sanskrit Buddhist texts are divided into two categories: 'Kangyur' and 'Tengyur'. Combined, in terms of length, it contains 325 scrolls of the largest folio in total. As a result, given not just a European scholar but even the most erudite scholar of Buddhism in the world, how could it be possible for them to contend that they had read all the Buddhist scriptures in their entirety? And this is without even mentioning the whole of commentaries on scriptures and treatises written by later generations. ${ }^{8}$ It is thus clear that Müller faced considerable difficulty when it came to researching the complete body of Buddhist scriptures, but he did have a relatively comprehensive understanding of this problem. He said, 'We possess the whole sacred canon of the Buddhists in various languages, in Pali, Burmese, and Siamese, in Sanskrit, Tibetan, Mongolian, and Chinese, and it is our fault entirely if as yet there is no complete translation in any European tongue of this important collection of sacred books."

Buddhism originated in India, and it was originally an Aryan religion. After entering China, it formed Chinese Buddhism, and numerous additional Buddhist scriptures were produced. Max Müller himself transcended Eurocentric points of view and instead used a globalised perspective to regard and interpret the reasons as to why Buddhist scriptures took on characteristics specific to different languages when they were disseminated into different regions and ethnic groups. He proposed that Ceylon (Sri Lanka), Myanmar (Burma), and Siam (Thailand) should constitute one form of Buddhism, while the religion's presence in Nepal, Tibet, Mongolia, China, Korea,

\footnotetext{
8 Müller, Science of Religion, 18-19 (44).

9 Müller, 18-19(44).
} 
and Japan should be distinguished as a different form. In China, Northern Buddhist scriptures principally used Sanskrit while those used by Southern Buddhists primarily employed Pali, and it is only by matching them together that they can reflect the entire content of Buddhist scriptures.

Before Max Müller began translating Buddhist scriptures, Buddhism was a religion that hadn't received much attention from Europeans, and there were only a few scholars of Oriental studies who had produced fragmented translations of Buddhism or researched it. In 1836, for example, the French Sinologist Jean Pierre Abel-Rémusat (1788-1832) translated into French and published Foӗ Kouӗ Ki (佛國記 or Relation des royaumes bouddhiques) by Faxian 法顯 (337?-422?) of the Eastern Jin Dynasty 東晉 (317-420 CE). ${ }^{10}$ This is believed to be the first rigorous effort to research Buddhism in the west. ${ }^{11}$ The French Oriental scholar Eugene Burnouf (1801-1852) published Essai sur le Pali jointly with Christian Lassen (1800-1876) in 1826, and he also translated The Lotus Sutra into French. However, relying on the dried palm leaf manuscripts which were collected by British Resident Minister to Nepal Brian Houghton Hodgson and were then donated to the University of London and Oxford University, Burnouf collated and published the 1854 work Introduction a l'bistorie du Buddhisme indien (印度佛教史導論). It is worth noting that Müller was a student of Burnouf, it is the definite influence of Burnouf that Müller began to pay attention to Indian Buddhism's Sanskrit scriptures, beginning with the study of Sanskrit.

During the second half of the nineteenth century, along with

10 Foguo ji 佛國記 is also known as Liyou Tianlan ji 歷游天竺記 and Faxian zhuan 法顯傳. It is a record of what the monk Faxian heard and saw during his trip through the Indian subcontinent that lasted from 399 to $413 \mathrm{CE}$.

11 It is worth noting that it was after both Relation des royaumes bouddhiques was translated into French and Jean Pierre Abel- Rémusat passed away in 1836 that the work was titled Relation des royaumes bouddhiques de Fabien and published. This was the first western work that diligently studied Buddhism, and from the perspective of seventeenth and eighteenth century European sinologists, Buddhism was a severely belittled religion. See Shen, Ouzhou Zhongguo Xue, 69. 
Europe's growing interest in Sinology, work on translating Buddhist scriptures into English eventually commenced in China and Europe. Such British missionaries to China as Joseph Edkins (1823-1905), Ernest John Eitel (1838-1908), Samuel Beal (1825-1889), and Timothy Richard (1845-1919) ${ }^{12}$ no longer simplified Buddhism as a superstitious form of idol worship in the way that the Jesuits and early Protestant missionaries did. Instead, they began to academically research Chinese Buddhism (for example, Ernest John Eitel initially put some efforts in compiling Chinese Buddhist dictionaries, and Samuel Beal also wrote a great deal about the religion). ${ }^{13}$ Their fundamental goal was certainly to understand the Sinicisation of Buddhism in order to promote the growth of Christianity, but this signifies that the research on Buddhism as carried out by missionaries had entered a new stage. And the English translations of Buddhist scriptures published in Europe formed into 'book series'. Among them, the most famous is one that was compiled by Max Müller under the name Sacred Books of the East. ${ }^{14}$

Max Müller led a number of Orientalists to carry out the translation of Buddhist scriptures, which was organised in a relatively

12 In the introduction to the second edition of Chinese Buddhism, Joseph Edkins wrote in the preface, 'As late as 1879 , very few people have researched this topic ... over 40 years ago I started to research Chinese Buddhism, and Professor Ernest John Eitel and Pastor Samuel Beal soon after began to research Chinese Buddhism, and they did very good work. Before they began to publish papers related to Chinese Buddhism, I had already pointed out that several centuries prior many sects of Chinese Buddhism had already been transmitted to Japan and taken root there.' From 1854 to 1855 , Edkins published a series of articles about the research of Buddhism in The North China Herald, and in 1859 he also published a book titled Religion in China. According to Henry Cordier's Bibliotheca Sinica, Joseph Edkins was the first missionary to China to use English to write papers regarding Buddhism. He used an academic perspective to research Buddhism relatively early, and he was also the first missionary to China who translated Chinese Buddhist scriptures into English.

$13 \mathrm{Li}$, 'Yazhou de fuyinshu'.

14 Published by the Oxford University Press from 1879 to 1910. 
systematic manner under the framework of Sacred Books of the East. When Müller wrote Introduction to the Science of Religion, he pondered, 'Buddhism has of late occupied so large a share of public interest that we thought it right to have it presented as fully as possible in its different phases. ${ }^{\prime 15}$ Consequently, he planned to publish a 24-volume work titled Sacred Books of the East that would cover English translations of such ancient Eastern religions as Brahmanism, Buddhism, Zoroastrianism, Islam and Chinese Confucian and Daoist classics. The objective of this was to better introduce Eastern religions to Europeans. ${ }^{16}$

Beginning in 1876, Max Müller received the support of the British Royal Society, which united a group of European Orientalists to begin work on compiling and translating the Sacred Books of the East. Faced with the questions of what Buddhist scriptures should be translated and how they should be translated, Müller earnestly considered and meticulously made selections: 'The Sacred Books of the Buddhists will be translated chiefly from two original collections, the Southern in Pali, the Northern in Sanskrit. Here the selection will, no doubt, be most difficult. Among the first books to be published will be, I hope, Sutras from the Digha Nikaya, a part of the Vinaya-pitaka, the Dhammapada, the Divyavadana, the Lalita-Vistara, or legendary life of the Buddha. ${ }^{17}$ This project was even greater than his original plan, and in 1879 the first volume was published. Up to the point in 1910, after Müller passed away, 49 volumes were published. If the index compiled by Moriz Winternitz (1863-1937) is added to this figure, then in total Sacred Books of the East published 50 volumes. Among them, more than 30 volumes were ancient Indian religious scriptures, and they included Sanskrit, Pali, and Chinese translations of Hinayana and Mahayana Buddhist

\footnotetext{
15 Müller, Science of Religion, 331 (224).

16 Regarding the initial conceptions over the compilation of the Sacred Books of the East, please consult 'Letter to the Very Rev. the Dean of Christ Church' and 'The Sacred Books of the East', which are contained in Müller's work Introduction to the Science of Religion.

17 Müller, Science of Religion, 305 (219).
} 
scriptures. For example, the 10th volume included the Dhammapada and Sutta-nipāta, which were jointly translated by Müller and Viggo Fausboll (1821-1908); the 11th volume included the Buddhist suttas as translated by Thomas Rhys Davids (1843-1922); the 13th, 17th, and 20th volumes included Davids and Hermann Oldenberg's (1854-1920) joint translation of Vinayapitaka, which includes the Pratimoksa, Mahāvagga, and Cullavagga; the 19th volume was translated by Samuel Beal from the Chinese version of the Buddhacarita (Fo suoxing zan 佛所行讚); the 21st volume was H. Kern's (1833-1917) translation of the Lotus Sutra from a Nepalese Sanskrit source material; the 35th and 36th volumes featured Davids' translation of the The Questions of King Milinda (Skt. Milindapañha; Chin. Milantuo wang wen jing 彌蘭陀王問 經); ${ }^{18}$ and the 49th volume contains the translation of Buddhist Mahâyâna Texts, which was jointly done by Edward Byles Cowell (1826-1903) and Müller. ${ }^{19}$ Yet, when compared to the vast sea of Buddhist scriptures, the Sacred Books of the East can still only be said to include a few important works.

As a linguist, Max Müller always regarded Sanskrit as mother tongue of the Indo-European family. With Buddhist scriptures, he first collated the Sanskrit and then translated it into English. Take, for example, the Shorter Sukhāvativyüha Sutra's (collated into Sanskrit in 1881 and translated into English in 1894), the Longer Sukhāvatìvyūha Sütra (collated into Sanskrit in 1883 and translated into English in 1894), the Diamond Sutra (collated into Sanskrit in 1881 and translated into English in 1894), and the Heart Sutra (collated into Sanskrit in 1884 and translated into English in 1894). Throughout this process, he received the help from the Japanese scholars Nanjō Bunyu 南條文雄 (1849-1927), Takakusu Junjirō

18 Milinda Panha is a Theravada Buddhism Pali scripture that records a dialogue about Buddhism that was held between the Greek King Milinda, who ruled over the northwestern part of India, and the monk Nāgasena. Eventually, Milinda is indoctrinated by Nāgasena and takes refuge in Buddhism, and as a result its title is translated into Chinese as The Scripture of Nägasena (Naxian biqiu jing 那先比丘經).

19 Li, Oumei Fojiao xueshu shi, 509-10. 
高楠順次郎 (1866-1945), and Chikuhara Kenju 笂原研壽 (18521883 ) on translation. The compilation and translation of Sacred Books of the East also inspired a number of talented individuals who diligently researched Buddhism, and it also led to further communication between academics of the East and West.

Nanjō Bunyu (1849-1927) was a scholar of the Japanese Shinshu Ōtani Buddhist sect and a native of Meinung (which is present-day Gifu Prefecture, Japan). His father was the Japanese Shinshu Buddhist monk Tani Eijun 溪英順. As a result, when Nanjō Bunyu was seven, he began studying the Three Pure Land Sutras (净土三經); when he was eight he also studied non-Buddhist classics with Hishida Shigeyoshi 菱田重禧 (1836-1895); when he was 18 he began to study and cultivate Shinshu Buddhism with Inaba Dōmeki 稻葉道貫 (1822-1896); and at 23 he became the adopted son of the Echizen 越前 (present-day Fukui Prefecture) monk Nanjō Shinkō 南條真興. It was for this reason that he changed his surname to Nanjō. Since Nanjō Bunyu was proficient at Chinese and English, Ōtani Kōei, then the 22nd Head Abbot of Higashi Honganji Temple and leader of Ōtani-ha Shinshu Buddhism, sent him to England to study in 1876. It was by sheer coincidence that he arrived at the University of Oxford when Max Müller was presenting his lectures on 'Comparative Religious and Linguistic Studies'.

Nanjō Bunyu studied Sanskrit with Max Müller and also helped him decipher Buddhist scriptures. Given that there were no set English terms for Buddhist concepts at that time, they cooperated on a meticulous translation of such Sanskrit works as Longer Sukhāvativyūha Sūtra, Diamond Sutra, Shorter Sukhāvativyūha Sūtra, Uṣnìsa Vijaya Dhärani Sutra, and the Heart Sutra. In order to introduce the Chinese translation of the Tripitaka to Western academic circles, in 1883, Nanjō Bunyu produced an English translation of the Da Ming sanzang shengjiao mulu 大明三藏聖教目錄 (Catalogue of the Chinese Translation of the Buddhist Tripitaka) included in the Japanese Huangbo edition of the Chinese Buddhist canon. He also provided some supplemental content for it. For example, at the beginning of the work he added a prologue and provided reference materials, and at the end of the work he added the name of the Indian author and Chinese translator, an interpretation catalogue of 
the author and an index. This work is also known as Nanjo Catalogue of the Chinese Translation of the Buddhist Tripitaka (南條目錄), and since it contained a comparative, phonetic listing of Chinese and Sanskrit terms with their English translation, it served as a great tool for European readers of Buddhist scriptures at that time.

It is worth noting that Max Müller first translated the extended and shortened versions of the Sanskrit Heart Sutra into Devanāgarī and a Roman phonetic script. ${ }^{20}$ Looking at this from modern standards, although some of the wording needed to be revised, Müller had a decent grasp of the original meanings of essential Sanskrit words from Dharma and also used a form of English expression that enabled Europeans of that time to easily understand its meanings. This allowed these translations of Buddhist scriptures to quickly promote dialogues, interactions, and integrations between the Eastern and Western worlds. Modern scholars have compared Müller's English translation of the Heart Sutra to Xuanzang's 玄牀 (602-664) Chinese translation, and they found that, in terms of the meaning of the text, the similarity of these two works was around 95 to 100 percent. ${ }^{21}$ As Buddhist scriptures have been continuously translated into English, Europeans have gradually come to understand the foreign Buddhist religion by reading its scriptures. This has not only promoted the rise of Buddhist research in Europe but, from the perspective of Sanskrit, it has also sparked a wave of interest in researching Asian Buddhism.

The fact that Buddhist Studies ascended to the lecture pulpits of Japanese universities during the Meiji period is closely related to Max Müller. Japanese figures of the modern era who took the initiative to be baptised in Western culture and research Buddhism included

20 The Indian script of Devanagari is a descendant of Brahmi. Its earliest-used books were written in Sanskrit. Today, the original form of Sanskrit has already disappeared, but currently the Devanagari script is one of the forms principally used for writing the official language of Hindi in India. Additionally, all of the Sanskrit Buddhist classics were also published using this script. Cf. Long, Yindu wenming, 51.

21 Zhang, Tujie Xinjing, 219. 
the likes of Nanjō Bunyu and Takakusu Junjirō, both of whom had gone to the University of Oxford to study Sanskrit with Müller and aid with his translations of Buddhist scriptures. After they returned to Japan, they 'employed their outstanding knowledge to exhibit the essentials of Buddhist studies at top universities, which fostered an interest in the youth to study Buddhism and gradually led to the start of a new phase in Japanese research of the religion. ${ }^{22}$ After Nanjō Bunyu returned to his home nation in 1884, he went first to Otani University in Kyōto and then to Tokyo Imperial University in Tōkyō to teach Sanskrit, and he was a precursor to the teaching of Sanskrit among Japanese Universities. Takakusu Junjirō was one of the Japanese scholars of Buddhism who researched Sanskrit, and he introduced modern western research on Buddhism to Japanese higher education. At Tokyo University, he set up a course on Buddhist studies and also held independent lectures on Buddhist studies. Influenced by Müller's Sacred Books of the East, Takakusu Junjirō's greatest contribution to Buddhist research was his compilation of the 100-volume Taishō shinshu daizōkyō 大正新修大藏經. Even to the present day, all scholars of Buddhism have either directly or indirectly benefitted from this contribution.

Max Müller translated Buddhist scriptures to meet the needs of comparative religious studies, but this also had the indirect effect of promoting the resurgence of Buddhist culture in modern-era China. When Yang Wenhui 楊文會 (1837-1911) was young, he greatly impressed Zeng Guofan 曾國藩 (1811-1872), and in 1878 he accompanied Zeng Jize 曾紀澤 (1839-1890) on diplomatic missions to England and France, where he could observe western politics and religions. That was also the time when European research of the East was in a state of vigorous growth. After Yang Wenhui met the Japanese scholar Nanjo Bunyu, who was studying abroad at that time, he also met Max Müller, with whom he developed a friendship. He also proactively studied philology methods with Müller so that he could collate Buddhist scriptures and perform research on Buddhism. This certainly had an influence on his career of studying Buddhism

22 Shi, 'Zhongri Fojiao', 669. 
and engraving scriptures. Yang Wenhui took it upon himself to seek out the true essence of Buddhism, and throughout the 30 years that followed, he and Nanjo Bunyu maintained an uninterrupted written correspondence. It is because of the help from the people like Nanjō Bunyu that Yang Wenhui was able to collect more than 300 types of once-lost Chinese Buddhist scriptures, commentaries, and writings of eminent monks from Japan and Korea, from which he selected and published in his engraved work Ten Sutras of the Pure Land Sect as Composed by Ancient Sages (彙刻古逸净土十書). ${ }^{23}$ At the same time, Yang Wenhui provided suggestions for the Supplement to Tripitaka (續藏經), which was engraved and printed by the Japanese Buddhism Sutra Academy, and he also provided them with a selection of rare and secret Buddhist scriptures to choose from. ${ }^{24}$ From the perspective of compiling scriptures, Yang Wenhui established cooperation between China and Japan regarding Buddhist studies in the modern era, and he also advanced academic interactions in the field of East Asian Buddhist culture. Yang Wenhui additionally translated Awakening of Faith in the Mabāyāna 大乘起信論 into English with the help of the English missionary Timothy Richard, which bolstered the dissemination of Buddhism in Europe, and such a method of working is in the same vein with Max Müller.

Although Max Müller did not entirely complete the great task of compiling Sacred Books of the East, it is still counted among the greatest achievements of Oriental studies and religious studies in the nineteenth century. In particular, these English translations of Buddhist scriptures ignited a passion within Europeans to attempt to understand and even research Buddhism, and it also sparked an interest in Asians to gain an understanding of Indian Buddhist scriptures by studying Sanskrit. This not only created a tradition among European academics at the outset of Buddhist research that placed equal emphasis upon philology and philosophy, but it also used translation as a means of recreating a culture, which in turn promoted cultural exchanges between the East and West.

\footnotetext{
23 Yang, 'Hui Ke Guyi Jintu Shi Shu Yuanqi', 195.

${ }^{24}$ Lou, 'Yang Renshan jushi xiaozhuan', 6.
} 


\section{A Unique Understanding of Buddhism and Principle Contribution to the Translation and Dissemination of Buddhist Scriptures}

With respect to providing translations of Buddhist scriptures that are both faithful to the spirit of the original and also beneficial to the reading habits of people from different backgrounds, Max Müller put his own opinion in writing:

The time had come when the ancient religions of the East should be studied in their own canonical texts, and that an end should thus be put to the vague assertions as to their nature and character, whether coming from the admirers or the detractors of those ancient creeds. To have left out what seems tedious and repulsive in them would have been to my mind simply dishonest, and I could have been no party to such an undertaking. The translations, as here published, are historical documents that cannot be tampered with without destroying their value altogether. It is for the historian to find out what is good and what is bad in them, and I still believe that he who has eyes to see will recognise that there are nuggets of gold to be found in these ancient books, all the more previous because hidden under so much rubbish, that is, under so much detritus of early thought. ${ }^{25}$

Müller believed that during the task of translating Buddhist scriptures, one should remain faithful to the original spirit and meaning of a work and that one could thereby gradually deepen their understanding of Buddhism. During his research of religious studies, he conducted comparative research upon things that had two or multiple characteristics in common or that possessed intrinsic connections. And when further investigating the origin and development of various religions' histories, Buddhism was frequently named as an example of an archetypal religion. In his eyes, Buddhism contained the common traits of a world religion while also having unique religious belief systems and methods of dissemination.

\footnotetext{
25 Müller, Science of Religion, 313 (225-26).
} 
First of all, in Buddhist scriptures, the mythical contents of Buddhism were compiled by the Buddha's disciples after his life as a means of glorifying their master, and such content existed with the intent of adding a sacred tint to the Buddha's aura:

The Buddhist legends teem with miserable miracles attributed to Buddha and his disciples-miracles which in wonderfulness certainly surpass the miracles of any other religion: yet in their own sacred canon a saying of Buddha's is record, prohibiting his disciples from working miracles, though challenged to do so by the multitudes, who required a sign that they might believe. And what is the miracle that Buddha commands his disciples to perform? 'Hide your good deeds,' he says, 'and confess before the world the sins you have committed.' That is the true miracle of Buddha. ${ }^{26}$

As a result, Max Müller believed, 'If we want to judge of a religion, we must try to study it as much as possible in the mind of its founder. ${ }^{27}$ The development of Indian Buddhism after the Buddha and the 'Buddhist council' of its sacred scriptures are connected:

We have in the history of Buddhism an excellent opportunity for watching the process by which a canon of sacred books is called into existence. We see here, as well as elsewhere, that during the lifetime of the teacher, no record of events, no sacred code containing the sayings of the master was wanted. His presence was enough, and thoughts of the future, and more particularly, of future greatness, seldom entered the minds of those who followed him. It was only after Buddha had left the world, that his disciples attempted to recall the sayings and doings of their departed friend and master. At that time, everything that seemed to redound to the glory of the Buddha, however extraordinary and incredible, was eagerly welcomed, while witnesses who would have ventured to criticise or reject unsupported statements, or to detract in any way from the holy character of

26 Müller, Science of Religion, 21 (16).

27 Müller, 191 (129). 
Buddha, had no chance of even being listened to. And when, in spite of all this, differences of opinion arose, they were not brought to the test by a careful weighing of evidence, but the names of 'unbeliever' and 'heretic' were quickly invented in India as elsewhere. ${ }^{28}$

On one hand, Max Müller pointed to the reasons for the content variety within Buddhist scripture, while on the other hand he believed that it is precisely because the Buddha's devout disciples constantly made his teachings more sacred and mystified that Buddhism's religious group was able to be constantly developed.

Second, Buddhism contains philosophical notions that are different from those of other religions. As Max Müller noted, 'The Buddhist [values] his perception of an eternal law, his submission to it, his gentleness, his pity. ${ }^{29}$ If compared with the highest deities of Indian Brahmanism, the Veda deities were all subordinates and worshippers of the highest deities, but the Buddha himself only seek out the so-called 'enlightenment'. From Müller's perspective, 'Buddhism and Christianity are indeed the two opposite poles with regard to the most essential points of religion: Buddhism ignoring all feeling of dependence on a higher power, and therefore denying the very existence of a supreme Deity; Christianity resting entirely on a belief in God as the Father, in the Son of Man as the Son of God, and making all men children of God by faith in His Son. Yet between the language of Buddha and his disciples and the language of Christ and His apostles there are strange coincidences. ${ }^{30}$ According to Buddhist history, it is evident that it was after the Shakyamuni Buddha gained enlightenment and attained Buddhahood that he began to announce to the masses the truth he realised. Principally, he preached the Four Nobel Truths and the Noble Eightfold Path. The first audiences to hear these teachings were Kaundinya and four others, who became the Buddha's earliest disciples and formed the early Sangha at Sarnath. These teachings are known as the 'Early turning of the

\footnotetext{
28 Müller, Science of Religion, 22-23 (17).

29 Müller, Origin and Growth of Religion, 386 (264).

30 Müller, Science of Religion, 171 (115).
} 
Wheel of Dharma' in Buddhist history. The 'Wheel of Dharma' (Dharmachakra) is a moniker for Dharma. It metaphorically explains how Dharma can rid sentient beings of their evil afflictions-just like the 'sacred wheel' of the ancient, mythical Indian king Chakravarti raja who could smash through mountains - and it also serves as an analogy for the Buddha's teachings, which are like a wheel that is forever turning. The Buddha's 'Early turning of the Wheel of Dharma' is of enormous significance in Buddhist history. This is because it formed the three major elements of Buddhism; namely, the Buddha, the Dharma, and the Sangha. From the moment, these 'three jewels' were possessed, early Buddhism can be said to have been established. ${ }^{31}$ Max Müller further emphasised the truths and wisdom announced from the Buddha's enlightenment. He believed that 'when he delivered for the first time the four fundamental doctrines of his system, he said, "Mendicants, for the attainment of these previously unknown doctrines, the eye, the knowledge, the wisdom, the clear perception, the light were developed within me". ${ }^{32}$ The Buddha's 'Four Noble Truths' are a supreme truth that transcends emotions and rationality, and the moral norms they conform to are the most consummate of their kind in the world. 'By this exalted virtue, Buddha, when he was freed from all desires, and had obtained divine knowledge, attained unto Buddhahood. Therefore, let a wise man, after he has turned away his desires from all pleasures, do good to all beings, even unto sacrificing his own life, that thus he may attain to true knowledge. ${ }^{33}$

Third, Buddhism possesses a kind of tolerance. Max Müller pointed out that, with perhaps the exception of the early phase of Buddhism, there is not a single other religion in the world that would approve of the notion of making impartial comparisons to all the other major world religions, and they would also not accept the academic discipline of the 'Science of Religion'. This is because, within Buddhism, sects were able to develop relatively independently

\footnotetext{
31 Hong, Zhongguo Fojiao, 3.

32 Müller, Science of Religion, 72 (52).

33 Müller, 172 (116).
} 
as long as they held on to the core faith. As a result, throughout its later periods of development, while Buddhism did always promote the Buddha's teachings - that is, the Four Noble Truths, the Five Aggregates (skandha), the Noble Eightfold Path, and the Twelve Links of Dependent Origination (pratityasamutpāda) —as the fundamentals of the faith, it also 'had greatly divergent understandings of many religious questions, and from these divergences we can observe the development and transformation of Buddhism. The difference between the stage of sectarian Buddhism and early Buddhism is that, besides manifesting the aforementioned differing perspectives on various precepts that led them to practice the religion differently, they prominently argued over various opinions of the Buddha, over what exactly is undergoing karma and samsara, and whether or not everything in the universe actually exists or not. ${ }^{34}$ From Max Müller's perspective, Buddhism needed to maintain the belief that the Buddha is 'omniscient' while also employing an attitude of tolerance in order to assimilate itself amid the different ethnic cultures of disparate regions; additionally, it needed to be able to completely eradicate any divergent notions among different sects. Such are the fundamental reasons that enabled Buddhism to maintain a tolerant nature throughout its development. He used Milindapañha as an example to provide further proof for this conclusion:

He was called Sarvagna or omniscient by his earlier pupils; but when in later times, it was seen that on several points Buddha had but spoken the language of his age, and had shared the errors current among his contemporaries with regard to the shape of the earth and the movement of the heavenly bodies, an important concession was made by Buddhist theologians. They limited the meaning of the word 'omniscient,' as applied to Buddha, to a knowledge of the principal doctrines of his system, and concerning these, but these only, they declared him to have been infallible. ... it certainly reflects great credit on the Buddhist theologians. In the Milindapañha, however, which is a canonical book, we see that the same idea was

\footnotetext{
34 Hong, Zhongguo Fojiao, 12.
} 
already rising in the mind of the great Nāgasena. Being asked by King Milinda whether Buddha is omniscient, he replies: 'Yes, Great king, the blessed Buddha is omniscient. But Buddha does not at all times exercise his omniscience. By meditation he knows all things; meditating he knows everything he desires to know.' In this reply a distinction is evidently intended between subjects that may be known by sense and reason, and subjects that can be known by meditation only. Within the domain of sense and reason, Nāgasena does not claim omniscience or infallibility for Buddha, but he claims for him both omniscience and infallibility in all that is to be perceived by meditation only, or, as we should say, in matters of faith..$^{35}$

In short, Max Müller's translation and dissemination of Buddhist scriptures makes four principal contributions.

First, with respect to the establishment of religious studies, he performed comparative research of Buddhism, Christianity, Judaism, Brahmanism, and ancient Persian Zoroastrianism from an extremely wide theoretical perspective and also a vigorously 'impartial' one. This was the first time the 'Science of Religion' concept was proposed, and it established this academic discipline.

Second, in terms of the dissemination of Buddhism throughout Europe, though Müller's translation and research of Buddhist scriptures are considered part of a period in time dominated by the research of Eastern and Indian cultures, he nevertheless still created a space for the 'otherised' religion of Buddhism to enter the European world. From the standpoint of impartiality, he advanced the dissemination of Buddhism in Europe and exchanges between the East and West regarding Buddhist culture.

Third, from a perspective of European Buddhist research, in response to people who unconsciously employed western notions to understand Buddhism, Max Müller used neither the perspective of belief nor philosophy to philosophically analyze or intuitively speculate about the phenomenon that is Buddhism; rather, preserving a rational attitude, he conducted academic research of religious

35 Müller, Science of Religion, 72-73 (52). 
phenomena by employing the method of comparative linguistics. Therefore, he developed his own specialties and techniques for understanding Buddhism during the course of translating Buddhist scriptures. Max Müller regarded Sanskrit as the source of the Aryan language family. Throughout the process of translating Sanskrit Buddhist scriptures into English, special emphasis was placed on using comparative linguistic methods. Within Buddhist studies research, special focus was given to performing textual research of exploring the etymology of the concepts in nouns. This facilitated research over longitudinal comparisons as to the origins and development of religions, and it vigorously sought to bring into view the original, 'pure' state of Buddhism. At the same time, importance was attached to performing cross-sectional comparative research between Buddhism and other religions as a means of revealing the special characteristics of Buddhist culture. As a result of searching for useful source material for comparative religious studies research, equal attention came to be placed on the academic paths of philology and philosophy in the European study of Buddhism.

Fourth, from the standpoint of research and the methods therein, Max Müller hoped to be able to transcend Christian traditional culture and the context of western academic knowledge and strive to use an academically neutral perspective to interpret the original meanings of Eastern Buddhism. Such a noble academic aspiration left a profound and long-lasting impression upon the advancement of Buddhist research in Europe in the modern era.

Of course, as a nineteenth century father of the science of religion, Max Müller's work translating and researching Buddhist scriptures was entirely devoted to the service of comparative religious studies. In terms of the effect this had on Buddhism and the research carried out by Buddhist studies, certain questions are still yet to be completely explored. One example is an understanding of the Buddhist faith and the fundamentals of the Buddhist doctrine, but it cannot be refuted that, after looking back over the work of the nineteenth century 'science of religion' figure represented by Max Müller, it had a meaningful impact upon present-day understandings and dialogues between different religions, and it also bolstered exchanges between academic culture in the East and West. 


\section{Bibliography}

Ch’en, Kenneth K. S. (Ch’en Guansheng) 陳觀勝, and Li Peizhu 李培茱, trans. Zongjiao xue daolun 宗教學導論 [Introduction to the Science of Religion by Max Müller]. Shanghai: Shanghai renmin chubanshe 上海人民出版社, 1989.

Hong Xiuping 洪修平. Zhongguo Fojiao wenbua licheng 中國佛教文 化歷程 [The Course of Chinese Buddhist Culture]. Revised and Extended Edition. Nanjing: Jiangsu jiaoyu chubanshe 江蘇教育 出版社, 2005.

Jin Ze 金澤, trans. Zongjiao de qiyuan yu fazhan 宗教的起源與發展 [Origin and Growth of Religion by Max F. Müller]. Shanghai: Shanghai renmin chubanshe 上海人民出版社, 1989.

Li Silong 李四龍. Oumei Fojiao xueshu shi 歐美佛教學術史 [History of European-American Buddhist Studies]. Beijing: Beijing University Press, 2009.

Li Xinde 李新德. “Yazhou de Fuyin shu”-Wanqing Xinjiao chuanjiaoshi Hanyu Fojiao jingdian Yingyi yanjiu’ 亞洲的福 音書 ——晚清新教傳教士漢語佛教經典英譯研究 [The Asian Gospel_Late Qing Protestant Missionary's English Translations of Buddhist Scriptures]. Shijie zongjiao yanjiu 世界宗教研究 [Studies in World Religions], no. 4 (2009): 50-60.

Long Changhuang 龍昌黃. Yindu wenming 印度文明 [Indian Civilization]. Beijing: Beijing chubanshe 北京出版社, 2008. Lou Yulie 樓宇烈. ‘Yang Renshan jushi xiaozhuan’ 楊仁山居士小傳 [Profile of Yang Renshan]. In Zhongguo xiandai xueshu jingdian: Yang Wenhui, OuyangJian, Lü ChengJuan 中國現代學術經典: 楊文會、歐陽漸、呂澂卷 [Academic Classics of China’s Modern Era: Volume on Yang Wenhui, Ouyang Jian, and Lü Cheng], by Lou Yulie, 3-7. Shijiazhuang: Hebei jiaoyu chubanshe 河北教育 出版社, 1996.

Lü Daji 呂大吉. 'Preface'. In Zongjiao xue daolun 宗教學導 論 [Introduction to the Science of Religion by Max Müller]. Translated by Chen Guansheng and Li Peizhu. Shanghai: Shanghai renmin chubanshe 上海人民出版社, 1989.

Müller, F. Max. Introduction to the Science of Religion. London: Longmans, Green, and Co., 1893. For its Chinese translation, see 
Ch'en and Li, trans., 1989.

- - L Lectures on the Origin and Growth of Religion. London:

Longmans, Green, and Co., 1878. For its Chinese translation, see Jin (trans.), 1989.

Shen Chonglin 沈崇麟, ed. Ouzhou Zhongguo xue 歐洲中國學

[European Sinology]. Beijing: Shehui kexue wenxian chubanshe 社會科學文獻出版社, 2005.

Shi Dongchu 釋東初. Zhongri Fojiao Jiaotong Shi 中日佛教交通 史 [History of Sino-Japanese Connections among Buddhism]. Dongchu Laoren Quanji 東初老人全集 [Complete Collection of Venerable Dongchu], no. 2. Taibei: Dongchu chubanshe 東初出 版社, 1985.

Sun Yiping 孫亦平. 'Zongjiao de Qiyuan yu Fazhan (1878)' 宗教的起 源與發展 (1878 年) [The Origin and Growth of Religion (1878)]. In Xifang zongjiao xue mingzhu tiyao 西方宗教學名著提要 (上) [The Summary of the Famous Works on Western Religious Studies (First Volume)]. Taibei: Zhaoming chubanshe 昭明出版 社, 2003.

Wach, Joachim. Bijiao zongjiao xue 比較宗教學 [The Comparative Study of Religions]. Taibei: Taiwan dacheng wenhua chubanshe 臺灣大乘文化出版社, 1980 .

Yang Renshan 楊仁山. 'Hui Ke Guyi Jingtu Shi Shu Yuanqi' 彙刻古 逸净土十書緣起 [Ten Sutras of the Pure Land Sect as Composed by Ancient Sages]. In Yang Renshan Dade Wenhui 楊仁山大德 文匯 [Collection of the Great Yang Renshan], by Yang Wenhui 楊文會, 195. Bainian Fojiao gaoseng dade congshu 百年佛教高 僧大德叢書 [Series on Eminent Monks over the Past Century]. Beijing: Huaxia chubanshe 華夏出版社, 2012.

Zhang Hongshi 張宏實. Tujie Xinjing 圖解心經 [Illustration of the Heart Sutra]. Haikou: Hainan chubanshe 海南出版社, 2010. 